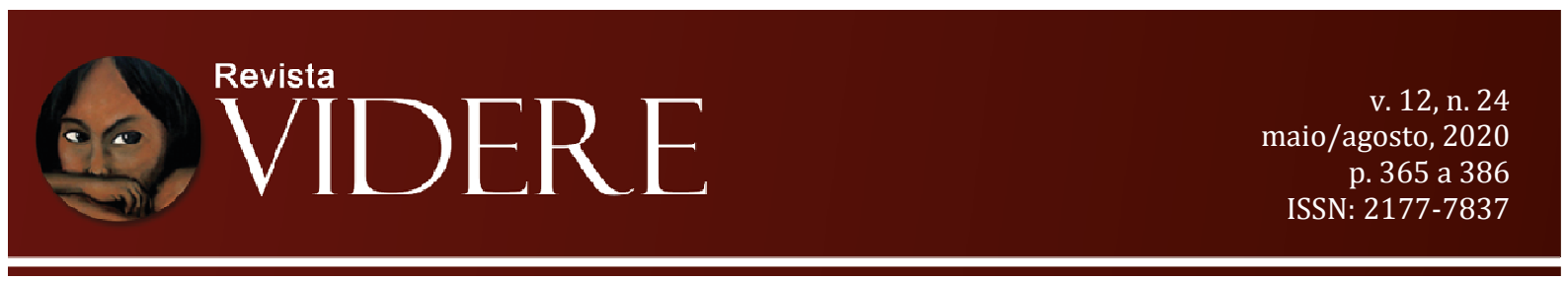

\title{
THE PERIODIC REPORTING PROCEDURE OF THE UNITED NATIONS SYSTEM AND THE HUMAN RIGHT TO WATER: OPPORTUNITIES AND CHALLENGES
}

\author{
O PROCEDIMENTO DE RELATÓRIOS PERIÓDICOS DO \\ SISTEMA DAS NAÇÕES UNIDAS E O DIREITO HUMANO À \\ ÁGUA: OPORTUNIDADES E DESAFIOS
}

Germana Aguiar Ribeiro do Nascimento Doutora em Direitos Humanos, Democracia e Justiça Internacional pela Universidad de Valencia (UV), Espanha. Mestre em Direitos Humanos (UCLY) - Universidad Católica de Lyon, França. E-mail: germana_aguiar@hotmail.fr OrcID: http://orcid.org/0000-0002-2942-3803

\begin{abstract}
Water is fundamental to life. Yet it was only in the 1970s that access to water began to be discussed at the international level as a human right. Before that, some United Nations Conventions and Treaties recognized the right to water in some way, but this right had to be inferred from other rights or was limited to a certain category of people. Regardless of their limitations, these texts can be seen to support the implementation of the human right to water, especially through their monitoring mechanisms: the periodic reporting procedure and the contentious cases. The objective of this article is to analyse the extent to which the periodic reporting procedure contributes to the implementation of the human right to water. To that aim, qualitative methodology will be used. Documentary research, the study of jurisprudence and international legislation will be used to support information regarding universal access to potable water. It seems that the periodic reporting procedure indeed reinforces the existence of a human right to water, but as far as its effective implementation is concerned, the contribution of this monitoring mechanism depends on the compliance of the countries.
\end{abstract}

Key words: Human Right to Water; United Nations System; monitoring; Reporting Procedures.

RESUMO: A água é fundamental para a vida. Contudo, foi apenas nos anos 70 que o acesso a este bem começou a ser discutido, a nível internacional, como um direito humano. Antes disso, algumas Convenções e Tratados das Nações Unidas reconheciam, de alguma forma, o direito à água, mas tal direito tinha que ser inferido de outros direitos ou estava limitado à uma determinada categoria de pessoas. Independentemente das suas limitações, estes textos podem reforçar a aplicação do direito humano à água, especialmente através dos seus mecanismos de monitoramento: os relatórios periódicos e os casos litigiosos. Assim, o objetivo deste artigo é analisar em que medida o mecanismo de relatórios periódicos pode contribuir à efetividade do direito humano à água. Para tal, a metodologia qualitativa será 
utilizada. A investigação documental, o estudo da jurisprudência e a legislação internacional apoiarão a informação relacionada ao tema. Parece que, de fato, os relatórios periódicos reforçam a existência de um direito humano à água autônomo, mas, no que se refere à sua efetiva aplicação, a contribuição deste mecanismo de monitoramento depende da conformidade dos países com suas obrigações legais.

Palavras-chave: direito humano à água; sistema das Nações Unidas; monitoramento; relatórios periódicos.

\section{Introduction}

Access to reliable and clean water is undoubtedly crucial for life. As Risse (2014, p. 178) states, we can live without other nutrients for long periods of time, but without water, we die within days. Despite that, many people around the world still do not have access to water. According to an estimate by the WHO/UNICEF Joint Monitoring Program for Water Supply and Sanitation, a total of 663 million people worldwide lacked improved drinking water sources in 2015, of which eight out of ten lived in rural areas (WHO/UNICEF, 2019, p. 7). Thus, it is important to consider access to water a human right. Winkler (2012, p. 228) adopts this point of view and acknowledges that "whereas access to water has been often considered a mere need, the human right to water translates it into a rightful claim”.

However, it took a long time for the international community to recognize this right as a human right. In fact, it was only in the seventies that the right to water started being discussed in the international arena as such. This process culminated in the adoption of the United Nations Resolution 64/292, which explicitly deemed access to clean water and sanitation a human right (2010). Before that, some Conventions and Treaties part of the United Nations system recognized the right to water, but this right had to be inferred from other rights or was limited to a certain category of people. Regardless of its limitations, these Conventions and Treaties contribute to the recognition and reinforcement of the human right to water, especially through its monitoring mechanisms.

In fact, the United Nations system is endowed with two sets of monitoring procedures: those established under human rights treaties, called conventional mechanisms, and those under the Human Rights Council, often called "non-treaty procedures or extraconventional procedures" (RODLEY, 2012, p. 320). Extra-conventional procedures refer to very specific situations ${ }^{159}$. One of them is the Special Rapporteur, an independent expert appointed by the Human Rights Council to examine and report on a country's situation or a

\footnotetext{
${ }^{159}$ To date, there are 44 thematic and 12 country mandates.
} 
specific human rights theme (BALDWIN-PASK; SCANNELLA, 2011, p. 419). A Special Rapporteur overseeing human rights to safe drinking water and sanitation was first appointed in $2008^{160}$. Even if his or her work is very relevant to the recognition of the human right to water, the analysis outlined here pays particular attention to how conventional monitoring mechanisms can be applied to further acknowledge the existence of this right.

These conventional mechanisms are part of some of the core instruments of the United Nations system that somehow refer to the right to water ${ }^{161}$ : the International Covenant on Civil and Political Rights (Human Rights Committee - HRC); the International Covenant on Economic, Social and Cultural Rights (ICESCR Committee); the Convention on the Elimination of Discrimination against Women (CEDAW Committee); the Convention on the Rights of the Child (CRC Committee); and the International Convention on the Rights of Persons with Disabilities (CRPD Committee).

These committees monitor the implementation of the treaty provisions by States, with the purpose of strengthening and protecting the human rights proclaimed. This function is carried out by the examination of periodic reports submitted by States and by adopting recommendations for improved implementation of the rights guaranteed by each text. Therefore, the aim of this article is to analyze the extent to which the human right to water is reinforced by these texts, and to examine the extent to which its monitoring mechanisms (the reporting procedures) contribute to the recognition of the human right to water.

\section{Strenghthening the human right to water through the reporting procedures}

A familiar requirement to be part of a treaty is the one that asks the States to submit reports about the implementation of the rights protected by treaties in their countries. Alston and Goodman highlight that this practice was considered revolutionary. At the time, it appeared as

\footnotetext{
${ }^{160}$ Catarina de Albuquerque was the first Rapporteur on the human rights to water and sanitation. After two mandates (2008-2014), she was replaced by Léo Heller (2014-2020). The appointment of the next Rapporteur will be made in October 2020.

${ }^{161}$ The United Nations system consists of nine core Conventions and their supervisory mechanisms: the International Covenant on Civil and Political Rights (Human Rights Committee); the International Covenant on Economic, Social and Cultural Rights (ICESCR Committee); the International Convention on the Elimination of all forms of Racial Discrimination (CERD Committee); the Convention on the Elimination of Discrimination against Women (CEDAW Committee); the Convention against Torture and other Cruel, Inhuman or Degrading Treatment (CAT Committee); the Convention on the Rights of the Child (CRC Committee); the International Convention on the Protection of the Rights of All Migrant Workers and Members of their Families (CMW Committee); the International Convention for the Protection of All Persons from Enforced Disappearance (CPED Committee); and the International Convention on the Rights of Persons with Disabilities (CRPD Committee).
} 
[i]t would have seemed nearly inconceivable that most of the world's states would periodically submit a report to an international body about their internal matters involving many politically sensitive aspects of relations between government and citizens, and then participate in a discussion about that report with members of that body drawn from all over the world (2013, p. 768).

In fact, the process of reporting allows the States to evaluate the measures they have taken to align their internal situation with the provisions of the treaty signed. The procedure for the analysis of reports is different for each Committee, but many core elements are similar to all of them. It is important to analyze how far the reporting proceedings of the Conventions and Treaties that somehow refer to the right to water have helped strenghten the implementation of this right.

2.1 The International Covenant on Civil and Political Rights (Human Rights Committee HRC)

The two International Covenants of 1966, the International Covenant on Civil and Political Rights and the International Covenant on Economic, Social and Cultural Rights, lack explicit references concerning the right to water. Notwithstanding, the right to water can be inferred from some of the clauses written in these two texts. As it is pointed out by Konuralp (2005, p. 158), "water is regarded as an integral component of other recognized rights, such as the rights to life, an adequate standard of living, health, housing and food".

In addition, in 1993, at the Vienna World Conference on Human Rights, the States underlined, in the context of a declaration and a plan of action, that

[a]ll human rights are universal, indivisible and interdependent and interrelated. The international community must treat human rights globally in a fair and equal manner, on the same footing, and with the same emphasis (UNITED NATIONS, 1993).

Consequently, all human rights, whether they be civil, political, economic, social or cultural, must be equally respected. Even if the right to water is not explicitly mentioned, it is directly related to other rights. Therefore, its realization is essential to the implementation of the rights stated.

When it comes to the International Covenant on Civil and Political Rights, entered into force in 1976, the right to life is guaranteed in Article 6. In General Comment N. 6, the Human Rights Committee states (1982, par. 5), "the right to life has been too often narrowly interpreted. The expression 'inherent right to life' cannot be properly understood in a 